\title{
Abnormal pulmonary function tests predict the development of radiation-induced pneumonitis in advanced non-small cell lung Cancer
}

L. Torre-Bouscoulet ${ }^{1,2}$, W. R. Muñoz-Montaño 3 , D. Martínez-Briseño ${ }^{4}$, F. J. Lozano-Ruiz ${ }^{5}$, R. Fernández-Plata ${ }^{4}$, J. A. Beck-Magaña ${ }^{3}$, C. García-Sancho ${ }^{4}$, A. Guzmán-Barragán ${ }^{4}$, E. Vergara ${ }^{3}$, M. Blake-Cerda ${ }^{5}$, L. Gochicoa-Rangel ${ }^{1,2}$, F. Maldonado ${ }^{5}$, M. Arroyo-Hernández ${ }^{3}$ and O. Arrieta ${ }^{3,6^{*}}$

\section{Abstract}

Background: Radiation pneumonitis (RP) is a frequent complication of concurrent chemoradiotherapy (CCRT) and is associated with severe symptoms that decrease quality of life and might result in pulmonary fibrosis or death. The aim of this study is to identify whether pulmonary function test (PFT) abnormalities may predict RP in nonsmall cell lung cancer (NSCLC) patients.

Methods: A prospective multi-institutional study was conducted with locally advanced and oligometastatic NSCLC patients. All participants were evaluated at baseline, end of CCRT, week 6, 12, 24, and 48 post-CCRT. They completed forced spirometry with a bronchodilator, body plethysmography, impulse oscillometry, carbon monoxide diffusing capacity (DLCO), molar mass of $\mathrm{CO}_{2}$, six-minute walk test and exhaled fraction of nitric oxide (FeNO). Radiation pneumonitis was assessed with RTOG and CTCAE. The protocol was registered in www. clinicaltrials.gov (NCT01580579), registered April 19, 2012.

Results: Fifty-two patients were enrolled; 37 completed one-year follow-up. RP $\geq$ Grade 2 was present in 11/37 (29\%) for RTOG and 15/37 (40\%) for CTCAE. Factors associated with RP were age over 60 years and hypofractionated dose. PFT abnormalities at baseline that correlated with the development of RP included lower forced expiratory volume in one second after bronchodilator $(p=0.02)$, DLCO $(p=0.02)$ and FeNO $(p=0.04)$. All PFT results decreased after CCRT and did not return to basal values at follow-up.

Conclusions: FEV 1 , DLCO and FeNO prior to CCRT predict the development of RP in NSCLC. This study suggests that all patients under CCRT should be assessed by PFT to identify high-risk patients for close follow-up and early treatment.

Keywords: Pneumonitis, Radiotherapy, Non-small cell lung Cancer, Pulmonary function tests

\footnotetext{
* Correspondence: ogarrieta@gmail.com
${ }^{3}$ Unidad Funcional de Oncología Torácica, Instituto Nacional de Cancerología (INCAN), Av. San Fernando No. 22, Col. Sección XVI, Tlalpan, 14080 Ciudad de México, CP, Mexico

${ }^{6}$ Thoracic Oncology Unit, Instituto Nacional de Cancerología, Ciudad de

México, México

Full list of author information is available at the end of the article
}

(c) The Author(s). 2018 Open Access This article is distributed under the terms of the Creative Commons Attribution 4.0 International License (http://creativecommons.org/licenses/by/4.0/), which permits unrestricted use, distribution, and reproduction in any medium, provided you give appropriate credit to the original author(s) and the source, provide a link to the Creative Commons license, and indicate if changes were made. The Creative Commons Public Domain Dedication waiver (http://creativecommons.org/publicdomain/zero/1.0/) applies to the data made available in this article, unless otherwise stated. 


\section{Background}

Lung cancer is the main cause of cancer-related mortality worldwide [1]. Non-small cell lung cancer (NSCLC) represents approximately $75 \%$ of the histological types of lung cancer. Despite the development of new diagnostic tools, in México most cases are diagnosed in an advanced stage [2]. Concurrent chemoradiotherapy (CCRT) is the standard treatment for locally advanced NSCLC [3], but the advantage in survival seen with CCRT is contrasted with an increase in toxicity $[4,5]$. Carboplatin with paclitaxel is one of the most commonly used schemes during CCRT, and it has demonstrated similar efficacy and less toxicity compared with etoposide and cisplatin when used with concurrent radiotherapy (RT) [6]. Furthermore, patients with oligometastatic disease can receive local control with CCRT, which might improve outcome [7-11].

Exposure to radiation frequently induces pulmonary toxicity, which can present as pneumonitis in a range from $15 \%$ and even up to $58 \%$ of the patients who receive radiotherapy, affecting quality of life (QoL) and oxygen dependence and leading to death in up to $50 \%$ of cases [12-14]. Several studies have identified patientrelated factors and the association between dose of RT administered and the radiation pneumonitis (RP) rate; however, predictive models have not been widely applied, as some of the research available includes heterogeneous groups of patients, radiation monotherapy, or non-lung malignancies. Thus, the correlation between pretreatment variables and the development of pneumonitis is not clear $[12,15]$.

A meta-analysis described that age over 65 years, dosimetric lung volume receiving $\geq 20$ Gy (V20) and CCRT schemes were predictive factors for RP [16]. Other studies did not find associations between age and RP [17-19]. V20 and mean lung dose (MLD) are the most consistent factors associated with RP in the literature [20]. Other factors associated with high RP frequency are related with gemcitabine [21].

Forced expiratory volume in one second $\left(\mathrm{FEV}_{1}\right)$ and carbon monoxide diffusing capacity (DLCO) are considered the mainstays for patient selection before major lung resection, although patients who do not meet the expected values may be candidates for CCRT. Still, there is no consistent evidence that supports their association and the development of RP. Some investigations reported that pulmonary function tests (PFT) predict RP with lower baseline $\mathrm{FEV}_{1}[19,22]$ and that $\mathrm{FEV}_{1} \%$ [23] and DLCO\% [24, 25] were significantly associated with risk of RP. A recent study with 260 patients showed that lower $\mathrm{FEV}_{1}$ is associated with a lower risk of RP [26], while other studies did not show significant correlations between PFT and RP [12, 27, 28].

Multiple studies reported the incidence of RP, although data was limited due to the number of patients, incomplete assessment of pulmonary functions, several chemotherapy schemes, different radiation therapy techniques and retrospective studies $[4,16,29]$. Despite all the available data, no study was specifically designed to describe the relationship between the incidence of RP and prediction values for pulmonary function tests.

The objective of this study was to determine whether baseline pulmonary function tests could identify patients with a high risk of developing RP after CCRT with carboplatin and paclitaxel in NSCLC patients with locally advanced and oligometastatic disease. Likewise, we describe the performance of spirometry with a bronchodilator, body plethysmography, impulse oscillometry, carbon monoxide diffusion capacity (DLCO), molar mass of carbon dioxide $\left(\mathrm{CO}_{2}\right)$, six-minute walk test and exhaled fraction of nitric oxide (FeNO).

\section{Methods \\ Study design}

A prospective, multi-institutional cohort study was conducted in patients with locally advanced NSCLC according to TNM 7 (clinical stage IIIA and IIIB) and oligometastatic disease (clinical stage IV) treated with CCRT from June 2013 to June 2015 at the Instituto Nacional de Cancerología in Mexico. Patients with oligometastatic disease were assessed by the multidisciplinary oncologic team to determine local control. The protocol was approved by the Scientific and Bioethical committees of the Instituto Nacional de Cancerología (013/014/ ICI; CEI/799) and the Instituto Nacional de Enfermedades Respiratorias in Mexico (C12-12). The protocol is registered in www.clinicaltrials.gov (NCT01580579). All patients signed informed consent and then were evaluated six times, on the initial visit, at the end of CCRT and at 6, 12, 24 and 48 weeks post-CCRT. At each visit, pulmonary function tests (spirometry with bronchodilator test, body plethysmography, impulse oscillometry, DLCO, FeNO, molar mass of carbon dioxide and sixminute walk test) were performed. Lung toxicity was evaluated with the Common Terminology Criteria for Adverse Events (CTCAE) V.4.0 and Radiation Therapy Oncology Group (RTOG). In this work, RP was considered to be pneumonitis grade 2 to 5 according to both scales.

\section{Chemotherapy}

Paclitaxel $50 \mathrm{mg} / \mathrm{m} 2$ was administered weekly for 6 weeks as an intravenous (IV) infusion over $1 \mathrm{~h}$ on days $1,8,15,22,29$, and 36 of the planned radiation course. All patients received the following premedications $1 \mathrm{~h}$ before the paclitaxel infusion: dexamethasone $20 \mathrm{mg} I \mathrm{~V}$; diphenhydramine $25 \mathrm{mg} \mathrm{IV}$; and ranitidine $50 \mathrm{mg}$ IV. After the paclitaxel infusion, weekly carboplatin at AUC 2.0, was delivered as an IV bolus infusion over $30 \mathrm{~min}$. Dose modifications were made in patients 
presenting grade 3 toxicity, restarting the treatment when the toxicity improved to grade 2 .

\section{Radiotherapy}

The patients went through 3D simulation, radiotherapy design and plan calculation was calculated with Varian Eclipse v.11.0 with dose corrected for tissue heterogeneity. Radiation therapy was administered 5 days per week (i.e., Monday to Friday) in 2 or 2,5Gy fractions daily by use of $6-18 \mathrm{MV} \mathrm{X}$ rays, using Varian IX or C-2100 linear accelerators. Conebeam CT was performed once a week. Three-dimensional conformal and intensity modulated radiation therapy were allowed. Radiation doses were prescribed to the planning target volume (PTV). The gross tumor volume was defined as the primary tumor and regionally involved nodes on $\mathrm{CT}$ when $1 \mathrm{~cm}$ or larger, or SUV uptake $>3$. Clinical target volume margins were $0.5-1.0 \mathrm{~cm}$, and PTV margins were $0.5-1.0 \mathrm{~cm}$ as well. The administered doses were 50 to 66 Gy in 20-33 fractions, and the following volume dose restrictions were recommended: $35 \%$ of affected lung parenchyma under 20 Gy (V20<35\%) and $65 \%$ of lung parenchyma under 5 Gy (V5<65\%) and a MLD of 20 Gy. Elective nodal irradiation was not permitted.

\section{Statistical analysis}

For descriptive purposes, continuous variables are presented as arithmetic means and standard deviation (SD). Median and quartile values were used to compare the medians considered to assess the pulmonary functions in each visit. To assess the differences throughout the study period, the Friedman test was used. Fisher's exact test was performed for categorical variables, and the Wilcoxon signed-rank test was used to analyze the changes in PFT continual variables. Cutoff points for PFTs were obtained using the Cutoff Finder version 2.1 [30] A value of $p \leq 0.05$ was considered statistically significant. Statistical tests were performed using STATA software ver. 12 (StataCorp, Lakeway Drive College Station, Texas, USA).

\section{Results \\ Patients}

A total of 52 patients were enrolled in the study, and 37 completed a one-year follow-up (CONSORT chart Fig. 1). The characteristics of patients at baseline are shown in Table 1 . There was male predominance (21 males $(56.8 \%)$ vs. 16 females (43.2\%) and the majority of patients were 60 years or older (64.9\%). Most patients had a smoking history $(n=20,54.1 \%)$ and a histological diagnosis of adenocarcinoma $(n=25,67.6 \%)$. Seventeen $(45.9 \%)$ patients presented locally advanced NSCLC and 20 patients (54.1\%) presented oligometastatic disease. The most common tumor localization was reported in the upper lobes $(15,40.5 \%)$, followed by lower $(13,35.2 \%)$ and medium ( 9 , $24.3 \%)$ lobes.

\section{Radiation pneumonitis incidence}

The incidence of RP varied according to the scale used. With the RTOG scale, 32/37 (86.4\%) patients developed RP (Grade 1, 56.7\%; Grade 2, 24.3\%; Grade 3, 2.7\%; Grade 4, 2.7\%), while with the CTCAE scale, 32/37 (86.4\%) patients developed RP (Grade 1, 45.9\%; Grade 2, 32.4\%; Grade 3, 5.4\%; Grade 4, 2.7\%). RP frequency with the RTOG

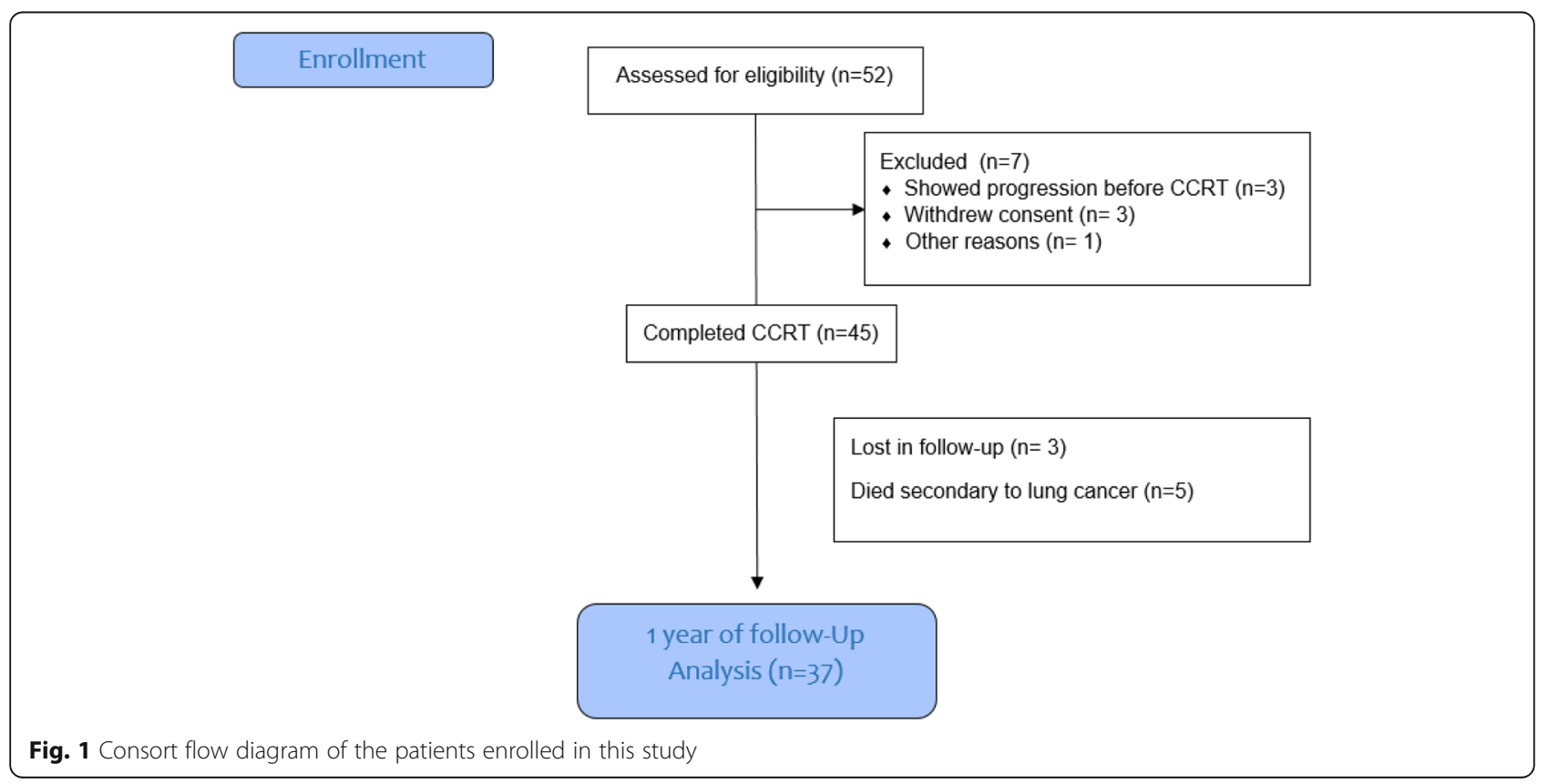


Table 1 Patient demographics and Tumor characteristics

\begin{tabular}{llll}
\hline Variable & & $\begin{array}{l}\text { Patients enrolled } \\
n=52(\%)\end{array}$ & $\begin{array}{l}\text { Patients with one-year follow-up } \\
n=37(\%)\end{array}$ \\
\hline Age years & $\leq 60$ & $20(38.4)$ & $13(35.1)$ \\
& $\geq 60$ & $32(61.6)$ & $24(64.9)$ \\
Sex & Female & $24(45.3)$ & $16(43.2)$ \\
Male & $0-1$ & $28(53.8)$ & $21(56.8)$ \\
${ }^{a}$ ECOG & $>2$ & $46(88.5)$ & $34(9.1)$ \\
Smoking history & Yes & $6(11.5)$ & $20(54.1)$ \\
& No & $22(42.3)$ & $17(45.9)$ \\
Current smoking & Yes & $30(57.7)$ & $5(13.5)$ \\
& No & $7(13.5)$ & $32(86.5)$ \\
Tobacco index & Package/Year & $45(86.5)$ & $34(0.3-111)$ \\
Histology & Adenocarcinoma & $38(0.3-111)$ & $25(67.6)$ \\
& Others & $35(67.3)$ & $12(32.4)$ \\
${ }^{b}$ Clinical stage & III & $17(32.7)$ & $17(45.9)$ \\
& IV & $26(50)$ & $20(54.1)$ \\
${ }^{c}$ Localization & Superior & $26(50)$ & $15(40.5)$ \\
& Medium & $11(21.1)$ & $9(24.3)$ \\
& Inferior & $12(23.1)$ & $13(35.2)$
\end{tabular}

${ }^{\mathrm{a}} \mathrm{ECOG}$ (Eastern Cooperative Oncology Group), performance status 0-fully active, 1-Restricted in physically strenuous activity, 2-Ambulatory and capable of all selfcare, 3-Capable of only limited selfcare, 4-Completely disabled and 5-Dead. ${ }^{b} 7$ th lung cancer TNM classification and staging system. ${ }^{c} \mathrm{CT}$ scan tumor localization

scale was associated with patients over 60 years old $(p=0.03)$. With the CTCAE scale, the development of RP was associated with patients over 60 years $(p=0.02)$ (Additional file 1: Table S1).

Baseline dosimetry characteristics comparing patients with the development of RP (grade $\geq 2$ ) are summarized in Table 2. The hypofractionated dose of 250 cGy was correlated with the development of RP according to the CTCAE scale $(p=0.036)$. With the RTOG scale, the development of RP was associated with PTV $\geq 350 \mathrm{~cm}^{3}$ $(p=0.013), \mathrm{V} 5 \geq 65 \%$, and $\mathrm{V} 20 \geq 35 \%$, and MLD over 20 Gy were not associated with RP development in any scale (Table 3).

\section{Pulmonary function tests}

The analysis of baseline characteristics between patients who developed RP and non-RP patients (Table 4) showed a correlation between baseline $\mathrm{FEV}_{1}$ in post-

Table 2 Dosimetric baseline characteristics of patients who developed RP and non-RP patients

\begin{tabular}{|c|c|c|c|c|c|c|}
\hline \multirow[t]{2}{*}{ Variable } & \multicolumn{3}{|l|}{ RTOG } & \multicolumn{3}{|l|}{ CTCAE } \\
\hline & No pneumonitis $n=26$ & Pneumonitis $n=11$ & $P$ value & No pneumonitis $n=22$ & Pneumonitis $n=15$ & $P$ value \\
\hline GTV $\left(\mathrm{cm}^{3}\right)$ & $75.6(41.3134)$ & $135(49.4265)$ & 0.17 & $80.8(39.8135)$ & $112(41.4252)$ & 0.52 \\
\hline PTV $\left(\mathrm{cm}^{3}\right)$ & $321(216,420)$ & $444(267,581)$ & 0.14 & $322(221,428)$ & $392(194,581)$ & 0.3 \\
\hline \multicolumn{7}{|c|}{ Absolute dose (Gy) } \\
\hline$\leq 60$ & $7(26.9)$ & $5(45.5)$ & 0.43 & $5(22.7 \%)$ & $7(46.7 \%)$ & 0.12 \\
\hline$>60$ & $19(73.1)$ & $6(54.5)$ & & $17(77.3 \%)$ & $8(53.3 \%)$ & \\
\hline \multicolumn{7}{|c|}{ Dose per fraction (cGy) } \\
\hline $180-200$ & $20(76.9 \%)$ & $5(45 \%)$ & 0.12 & $18(81.8 \%)$ & $7(50 \%)$ & 0.036 \\
\hline 250 & $6(23.1 \%)$ & $6(54 \%)$ & & $4(18.2 \%)$ & $8(50 \%)$ & \\
\hline \multicolumn{7}{|c|}{ Restriction dose (\%) } \\
\hline$\vee 5$ & $65(56.5,77.9)$ & $54.9(47,69.4)$ & 0.17 & $65.5(56,79)$ & $56.8(48,70)$ & 0.19 \\
\hline V 20 & $49.7(41,57.2)$ & $42(27.7,55.5)$ & 0.4 & $49.7(39,57.9)$ & $44(32,59.4)$ & 0.62 \\
\hline MLD (Gy) & $26(18.5,29.2)$ & $20(13,30)$ & 0.57 & $25.8(18,29.6)$ & $21.4(15,29)$ & 0.53 \\
\hline
\end{tabular}

GTV Gross tumoral volume, PTV Planning tumor volume, V 5 Volume of lung receiving at least 5 Gy, $V 20$ Volume of lung receiving at least 20 Gy, MLD Mean lung dose

Significant $P$ values in bold 
Table 3 Dosimetric baseline characteristics of patients who developed RP

\begin{tabular}{|c|c|c|c|c|c|c|c|}
\hline \multirow[t]{2}{*}{ Variable } & & \multicolumn{3}{|l|}{ RTOG } & \multicolumn{3}{|l|}{ CTCAE } \\
\hline & & No RP $n=26(\%)$ & Pneumonitis $n=11$ (\%) & $P$ value & No RP $n=22(\%)$ & Pneumonitis $n=15$ (\%) & $P$ value \\
\hline \multirow[t]{2}{*}{$\mathrm{GTV}\left(\mathrm{cm}^{3}\right)$} & $0-99.9$ & $16(61.5)$ & $4(36.4)$ & 0.078 & $13(59.1)$ & $6(40)$ & 0.324 \\
\hline & $\geq 100$ & $10(38.5)$ & $7(63.6)$ & & $9(40.9)$ & $9(60)$ & \\
\hline \multirow[t]{2}{*}{ PTV } & $0-349.9$ & $19(73.1)$ & $4(36.4)$ & 0.013 & $16(72.3)$ & $6(40)$ & 0.086 \\
\hline & $\geq 350$ & $7(26.9)$ & $7(63.6)$ & & $6(27.3)$ & $9(60)$ & \\
\hline \multirow[t]{2}{*}{ V $5(\%)$} & $0-64.9$ & $13(50)$ & $8(72.7)$ & 0.284 & $11(50)$ & $10(66.7)$ & 0.50 \\
\hline & $\geq 65$ & $13(50)$ & $3(27.3)$ & & $11(50)$ & $5(33.3)$ & \\
\hline \multirow[t]{2}{*}{ V 20 (\%) } & $0-34.9$ & $4(15.4)$ & $3(27.3)$ & 0.648 & $4(18.2)$ & $3(20)$ & 0.999 \\
\hline & $\geq 35$ & $22(84.6)$ & $8(72.7)$ & & $18(81.8)$ & $12(80)$ & \\
\hline \multirow[t]{2}{*}{ MLD (Gy) } & 0-19.9 & $10(38.5)$ & $5(45.5)$ & 0.727 & $9(40.1)$ & $7(46.7)$ & 0.748 \\
\hline & $\geq 20$ & $16(61.5)$ & $6(54.5)$ & & $13(59.1)$ & $8(53.3)$ & \\
\hline
\end{tabular}

GTV Gross tumoral volume, PTV Planning tumor volume, $V 5$ Volume of lung receiving at least 5 Gy $V 20$ Volume of lung receiving at least 20 Gy, MLD Mean lung dose

Significant $P$ values in bold

Table 4 Comparison of baseline pulmonary function tests results using RTOG and CTCAE scales

\begin{tabular}{|c|c|c|c|c|c|c|}
\hline \multirow{3}{*}{ Variable } & \multicolumn{2}{|l|}{ RTOG Scale* } & \multirow{3}{*}{$P$ value } & \multicolumn{2}{|l|}{ CTCAE Scale* } & \multirow{3}{*}{$P$ value } \\
\hline & No pneumonitis $(n=26)$ & Pneumonitis $(n=11)$ & & No pneumonitis $(n=22)$ & Pneumonitis $(n=15)$ & \\
\hline & median (p25, p75) & median (p25, p75) & & median (p25, p75) & median (p25, p75) & \\
\hline \multicolumn{7}{|l|}{ Spirometry } \\
\hline FEV1 post (\% predicted value) & $98(84,110)$ & $73(60,92)$ & 0.02 & $98(86,110)$ & $83(61,100)$ & 0.02 \\
\hline FVC post (\% predicted value) & $106(90,114)$ & $91(79,114)$ & 0.17 & $109(90,116)$ & $93(79,105)$ & 0.06 \\
\hline FEV1/FVC post (\%) & $77(72,81)$ & $65(54,74)$ & 0.01 & $75(70,82)$ & $70(58,79)$ & 0.07 \\
\hline \multicolumn{7}{|l|}{ Plethysmography } \\
\hline $\mathrm{TLC}(\mathrm{L})$ & $5.1(4.4,6.3)$ & $6.8(4.8,6.9)$ & 0.06 & $5.5(4.7,6.3)$ & $5.5(4,6.9)$ & 0.93 \\
\hline TLC (\% predicted value) & $101(88,111)$ & $102(94,113)$ & 0.63 & $103(95,113)$ & $99(86,111)$ & 0.25 \\
\hline RV/TLC (\%) & $39(35,44)$ & $50(38,59)$ & 0.01 & $38(34,44)$ & $45(38,56)$ & 0.02 \\
\hline \multicolumn{7}{|l|}{ Impulse oscillometry } \\
\hline $\operatorname{Rrs5}(\mathrm{Kpa} / \mathrm{L} / \mathrm{s})$ & $0.34(0.29,0.41)$ & $0.33(0.28,0.44)$ & 0.98 & $0.34(0.29,0.42)$ & $0.33(0.28,0.4)$ & 0.63 \\
\hline $\operatorname{Rrs} 20$ (Kpa/L/s) & $0.26(0.22,0.31)$ & $0.27(0.2,0.31)$ & 0.71 & $0.27(0.22,0.32)$ & $0.26(0.21,0.29)$ & 0.47 \\
\hline Xrs5 (Kpa/L/s) & $-0.13(-0.17,-0.1)$ & $-0.13(-0.17,-0.082)$ & 0.64 & $-0.13(-0.17,-0.1)$ & $-0.13(-0.17,-0.09)$ & 0.67 \\
\hline $\mathrm{AX}(\mathrm{Kpa} / \mathrm{L})$ & $0.55(0.45,1.3)$ & $0.81(0.4,1.2)$ & 0.88 & $0.55(0.45,1.3)$ & $0.67(0.47,1.2)$ & 0.77 \\
\hline \multicolumn{7}{|c|}{ Carbon Monoxide Diffusing Capacity } \\
\hline $\mathrm{DLCO}(\mathrm{mL} / \mathrm{min} / \mathrm{mmHg})$ & $20(17,24)$ & $16(10,19)$ & 0.06 & $22(18,25)$ & $16(12,19)$ & 0.02 \\
\hline DLCO (\% predicted value) & $91(76,110)$ & $66(51,98)$ & 0.06 & $92(76,111)$ & $71(58,98)$ & 0.049 \\
\hline \multicolumn{7}{|l|}{ Molar mass of carbon dioxide } \\
\hline PO2 (mmHg) & $66(61,69)$ & $60(52,68)$ & 0.14 & $67(61,70)$ & $60(57,68)$ & 0.07 \\
\hline $\mathrm{pCO} 2(\mathrm{mmHg})$ & $29(27,31)$ & $31(26,34)$ & 0.17 & $30(25,32)$ & $29(27,33)$ & 0.65 \\
\hline $\mathrm{SO} 2(\%)$ & $92(91,94)$ & $92(87,94)$ & 0.32 & $92(91,94)$ & $92(87,94)$ & 0.21 \\
\hline \multicolumn{7}{|l|}{ Six-minute walk } \\
\hline Distance (m) & $487(379,510)$ & $429(367,481)$ & 0.16 & $495(369,510)$ & $435(404,482)$ & 0.34 \\
\hline \multicolumn{7}{|l|}{ Fraction of exhaled nitric oxide } \\
\hline FENO & $15(10,18)$ & $24(19,53)$ & 0.01 & $15(11,18)$ & $23(16,30)$ & 0.04 \\
\hline
\end{tabular}

FEV Forced expiratory volume, FVC Forced vital capacity, $F E V_{1}$, forced expiratory volume in one second, TLC Total lung capacity, RV Residual volume, Rrs 5 Resistance at $5 \mathrm{~Hz}$, Rrs 20 Resistance at $20 \mathrm{~Hz}$, Xrs 5 Reactance at $5 \mathrm{~Hz}$, AX Reactance Area, DLCO Diffusing capacity of the lung for CO, FeNO Fraction of exhaled Nitric Oxide. ${ }^{*}$ Wilcoxon rank-sum test for unmatched data was used to compare respiratory variables Significant $P$ values in bold 
bronchodilator spirometry (\% of predicted value) and FeNO with the development of RP using both RTOG ( $p$ $=0.02$ and $p=0.01$, respectively) and CTCAE scales ( $p=$ 0.02 and $p=0.04$, respectively). The ratio of the $\mathrm{FEV}_{1}$ in post-bronchodilator spirometry (\% of predicted value) and FVC had statistical significance using the RTOG scale $(p$ $=0.01)$. Lower values of DLCO $(\mathrm{mL} / \mathrm{min} / \mathrm{mmHg})$ and DLCO (\% predicted) in the baseline test correlated with $\mathrm{RP}$ only in the CTCAE scale $(\mathrm{p}=0.02$ and 0.049 , respectively). According to the RTOG scale, the $p$ value was borderline ( $p=0.06$ and 0.06 , respectively). The best cutoff point values associated with RP development were $\mathrm{FEV}_{1} \leq$ 1.9 (Lts.) for the RTOG scale (HR 1.35, 95\% CI 0.72-2.51) , FEV $\leq 1.9$ (Lts) for the CTCAE scale (HR 3.21, 95\% CI 0. 93-11.16); FeNO $\geq 18.5$ for the RTOG scale (HR 1.99, 95\% CI 1.22-3.24), FeNO $\geq 17.5$ for the CTCAE scale (HR 1.9, 95\% CI 1.10-3.28), DLCO $\leq 16.9$ for the RTOG scale (HR 1.81, 95\% CI $0.97-3.34$ ), and DLCO $\leq 18.9$ for CTCAE scale (HR 2.26, 95\% CI 1.21-4.22). These data are described in Table 5. Other tests, such as plethysmography, molar mass of $\mathrm{CO}_{2}$, impulse oscillometry, and the 6-min walk test did not have any association with patients at high risk for RP. Figure 2 shows the changes after CCRT in $\mathrm{FEV}_{1}, \mathrm{FeNO}$ and DLCO.

Overall PFT had detrimental changes with statistical significance, and none of them recovered to their baseline values. Patients who developed RP, or not, also presented decrease in the spirometry, plethysmography, and

Table 5 Univariable analysis for cutoff points of Pulmonary Function tests and Pneumonitis

\begin{tabular}{|c|c|c|c|c|c|c|}
\hline \multicolumn{7}{|c|}{ RTOG Scale } \\
\hline PFT & $\begin{array}{l}\text { Cutoff } \\
\text { point }\end{array}$ & $\begin{array}{l}\text { No } \\
\text { Pneumonitis }\end{array}$ & Pneumonitis & $\mathrm{HR}$ & $95 \% \mathrm{Cl}$ & $\begin{array}{l}P \\
\text { value }\end{array}$ \\
\hline \multirow[t]{2}{*}{ FEV1 } & $<1.9$ & $5(19.2 \%)$ & $4(36.4 \%)$ & \multirow[t]{2}{*}{1.35} & \multirow{2}{*}{$\begin{array}{l}0.72- \\
2.51\end{array}$} & \multirow[t]{2}{*}{0.404} \\
\hline & $\geq 1.9$ & 21 (80.8\%) & 7 (63.6\%) & & & \\
\hline \multirow[t]{2}{*}{ FeNO } & $<18.5$ & 17 (65.4\%) & 1 (9.1\%) & \multirow[t]{2}{*}{1.99} & \multirow{2}{*}{$\begin{array}{l}1.22- \\
3.24\end{array}$} & \multirow[t]{2}{*}{0.003} \\
\hline & $\geq 18.5$ & 9 (34.6\%) & 10 (90.9\%) & & & \\
\hline \multirow[t]{2}{*}{ DLCO } & $<16.9$ & 6 (23.1\%) & 7 (63.6\%) & \multirow[t]{2}{*}{1.81} & \multirow{2}{*}{$\begin{array}{l}0.97- \\
3.34\end{array}$} & \multirow[t]{2}{*}{0.028} \\
\hline & $\geq 16.9$ & $20(76.9 \%)$ & $4(36.4 \%)$ & & & \\
\hline \multicolumn{7}{|c|}{ CTCAE Scale } \\
\hline PFT & $\begin{array}{l}\text { Cutoff } \\
\text { point }\end{array}$ & $\begin{array}{l}\text { No } \\
\text { Pneumonitis }\end{array}$ & Pneumonitis & $\mathrm{HR}$ & $95 \% \mathrm{Cl}$ & $\begin{array}{l}P \\
\text { value }\end{array}$ \\
\hline \multirow[t]{2}{*}{ FEV1 } & $<1.9$ & 2 (9.1\%) & 7 (46.7\%) & \multirow{2}{*}{3.21} & \multirow{2}{*}{$\begin{array}{l}0.93- \\
11.16\end{array}$} & \multirow[t]{2}{*}{0.017} \\
\hline & $\geq 1.9$ & 20 (90.9\%) & 8 (53.3\%) & & & \\
\hline \multirow[t]{2}{*}{ FeNO } & $<17.5$ & 13 (59.1\%) & $3(20 \%)$ & \multirow[t]{2}{*}{1.90} & \multirow{2}{*}{$\begin{array}{l}1.10- \\
3.28\end{array}$} & \multirow[t]{2}{*}{0.041} \\
\hline & $\geq 17.5$ & 9 (40.9\%) & 12 (80\%) & & & \\
\hline \multirow[t]{2}{*}{ DLCO } & $<18.9$ & 7 (31.2\%) & $12(80 \%)$ & \multirow[t]{2}{*}{2.26} & \multirow{2}{*}{$\begin{array}{l}1.21- \\
4.22\end{array}$} & \multirow[t]{2}{*}{0.007} \\
\hline & $\geq 18.9$ & 15 (68.2\%) & $3(20 \%)$ & & & \\
\hline
\end{tabular}

$F E V_{1}$ forced expiratory volume in one second, FeNO Fraction of exhaled Nitric Oxide, DLCO Diffusing capacity of the lung for $\mathrm{CO}, \mathrm{HR}$ Hazard ratio, $\mathrm{Cl}$ confidence interval

Significant $P$ values in bold diffusion capacity of the lung for carbon monoxide using both scales. These changes were not associated with the development of RP grade $\geq 2$ (Additional file 1: Table S1).

\section{Discussion}

Radiation pneumonitis (RP) is the most important complication related to CCRT, as it impairs respiratory function and decreases the quality of life [13, 14, 31]. The incidence of RP fluctuates from 15 to $58 \%$, and this range could be explained by its evaluation methods, symptom assessment, awareness of the disease and different radiation techniques [16, 31-33]. In this work, we found an incidence of $86.4 \%$ using the ROTG scale and $86.4 \%$ according to the CTCAE scale; however, RP with clinical relevance (Grade $\geq 2$ ), was $29.7 \%$ for RTOG and $40.5 \%$ for CTCAE scales.

In our study, being 60 years of age or older was a predicting factor of RP, which is consistent with several publications that have documented age as a risk factor in radiotherapy [14, 16]; however, neither sex nor functional class were able to predict this complication. The association between smoking and radiation-induced lung toxicity was controversial, it has been reported that smoking history or active smoking are protective factors against pneumonitis [34]. This could be because smoking-damaged lungs may not be as sensitive to radiation injury as healthy lungs, and this may possibly be due to tobacco-induced immunosuppression or by the presence of nonfunctional airspace in these lungs [35, 36]. However, this study did not show any trend related to these factors. The frequency of smoking habit in our sample was low (52\%), and this finding could be explained by other factors [37, 38].

Several studies have reported that CCRT affects the pulmonary function, but there is limited information on the adequate identification of high-risk patients who could develop RP [16]. With respect to the dosimetric variables of radiotherapy, we found that PTV greater than 350 is associated with RP; in this work, we did not find that non-compliance with recommended restriction doses (PA V $5<65 \%$, PAV $20<35 \%$ and MLD $<20$ Gy) were associated with the development of RP, although it has been previously reported $[13,16,39]$. Dose per fraction over 250 (cGy) was the only dosimetric variable that showed a statistically significant association with the development of RP, according to the CTCAE scale, this finding can be explained by the fact that hypofractionated doses have a great biological impact [40, 41]. Therefore, we suggest discontinuing this fractionation scheme, even in patients with palliative schemes.

Chronic obstructive pulmonary disease and pulmonary emphysema are common comorbidities in lung cancer [2], although many cancer patients do not have the criteria for these diseases, and alterations in PFT results 

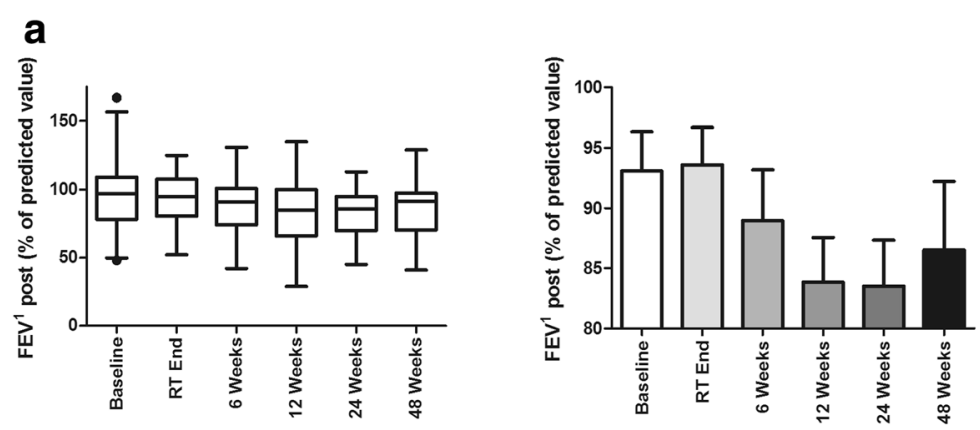

b

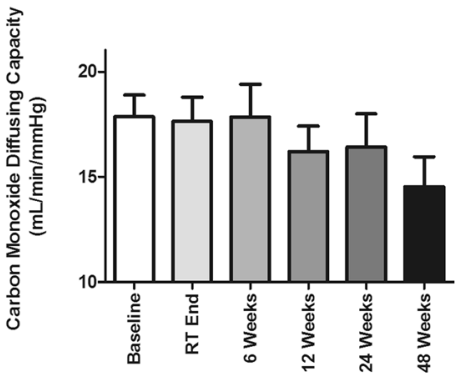

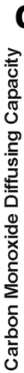
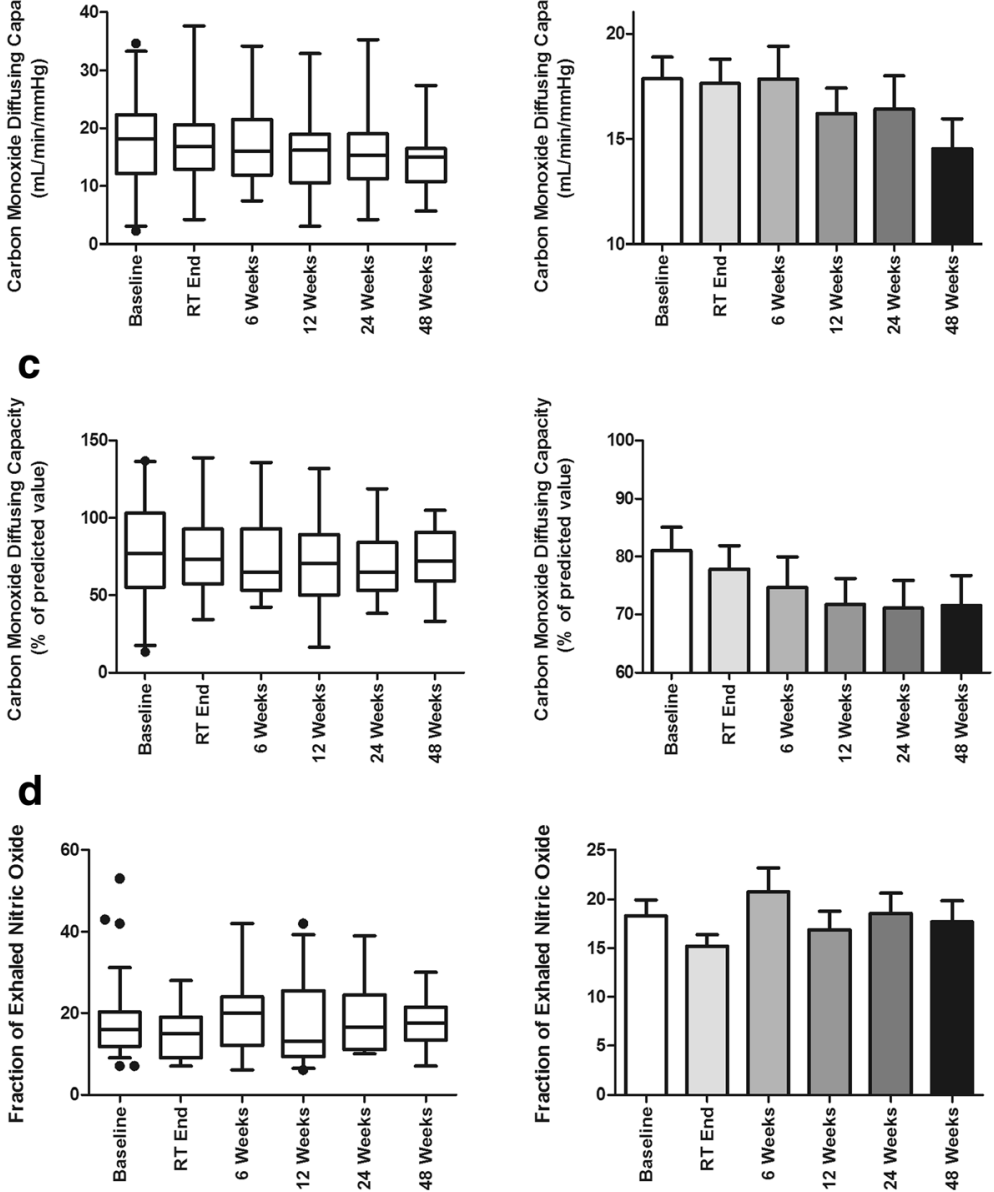

Fig. 2 Changes in PFT tests during follow up, (a) FEV1, (b) Carbon Monoxide Diffusing Capacity, (c) Fraction of exhaled nitric oxide

are common. The baseline results of two of the PFTs showed that the spirometry and fractional concentrations of exhaled nitric oxide (FeNO) showed statistically significant differences between the patients who developed RP and the patients who did not develop RP, according to both scales; this implies that patients with impaired lung capacity prior to CCRT had a higher risk of presenting RP [42].

In the results of spirometry, alterations in $\mathrm{FEV}_{1}$ showed a statistically significant association with the development of PR; the higher this value is in the initial evaluation, the better the prognosis for the patients. One of the most interesting findings of this work is the relationship between FeNO and the development of PR, given that nitric oxide in expired air is a noninvasive marker of airway inflammation. It has been used in the diagnosis and follow-up of patients with inflammatory pulmonary diseases $[43,44]$. Patients with elevated FeNO levels had an increased risk of developing RP according to both scales, which strongly suggests that 
those patients who already had a basal inflammatory reaction, such as emphysema or COPD, likely due to neoplasms or comorbidity, were more likely to develop PR. During follow-up, FeNO continued to increase, even exceeding $20 \%$ at its peak at week 6 of CCRT, given that inflammation was expected to decline after CCRT. According to anticipations, FeNO levels had a partial recovery but failed to reach the initial value. To the best of our knowledge, this is the first work that reports the relationship between FENO and RP development after CCRT. However, further studies are required to confirm this finding and support the addition of this test to the standard PFT battery $[45,46]$. The results of the diffusion capacity of the lung for the carbon monoxide test (DLCO) showed that the patients who had a lower pulmonary diffusion of basal carbon monoxide and percentage of the predicted value developed RP using the CTCAE scale and was borderline with the RTOG scale. In a similar way, there are reports that suggest that impaired baseline DLCO could predict the development of $\mathrm{RP}$, in the same way, it has been reported that small affectations in DLCO after SABR, can significantly impact the symptomatology of patients with NSCLC, which reinforces the idea of including this test in the close monitoring of patients with NSCLC [20,25].

Our study shows that CCRT causes a decrease in the overall PFT results. For example, $\mathrm{FEV}_{1}$ was decreased to $12 \%$, plethysmography (TLC) to $25 \%$ and diffusion capacity for carbon monoxide to $17 \%$. In a previously compromised patient, small changes such as these can significantly affect the outcome and favor the presentation of important clinical changes and oxygen dependence. These changes occur in all patients, with or without RP, so that changes in PFT after CCRT were not associated with the development of RP.

The limitation of our study is its small sample size. Nevertheless, the evaluation of pulmonary function was comprehensive, and all the patients had a follow-up of at least one year.

\section{Conclusion}

Age over 60 years and poor results in $\mathrm{FEV}_{1}$, DLCO and FeNO prior to CCRT predicted the development of RP in patients with NSCLC. This study suggests that all patients with advanced NSCLC who receive CCRT must be assessed by PFT before the start of treatment in order to identify patients at high risk for RP, provide a close follow-up, and consider the use of early treatment to reduce long-term complications. There is potential to investigate the utility of PFT as a predictor of pneumonitis. However, additional studies are required to accurately identify patients at greater risk and to provide effective preventive treatment.

\section{Additional file}

Additional file 1: Table S1. Patient characteristics based on RTOG and CTCAE criteria. (DOCX $19 \mathrm{~kb}$ )

\section{Abbreviations \\ CCRT: Concurrent chemoradiotherapy; $\mathrm{CO}_{2}$ : Carbon dioxide; \\ CTCAE: Common Terminology Criteria for Adverse Events; DLCO: Carbon monoxide diffusion capacity; FeNO: Exhaled fraction of nitric oxide; $\mathrm{FEV}_{1}$ : Forced expiratory volume in one second; MLD: Mean lung dose; NSCLC: Non-smalls Cell Lung Cancer; PFT: Pulmonary function tests; QoL: Quality of life; RP: Radiation pneumonitis; RT: Radiotherapy; RTOG: Radiation Therapy Oncology Group}

\section{Acknowledgments}

This work was presented at the International Association for the study of Lung Cancer (IASLC) World Conference on Lung Cancer, 4-7 December 2016, Vienna, Austria. Register number P2.02-062.

\section{Funding}

This work was supported by the National Council of Science and Technology of Mexico (CONACYT) [180466 to LTB].

Availability of data and materials

Please contact author for data requests.

\section{Authors' contributions}

$\mathrm{AO}$ and TBL designed the study and wrote the manuscript. MBD and AM carried out the statistical analysis. MMWR, LRFJ and EV contributed substantially to data analysis and results interpretation. The rest of the authors recruited patients and reviewed the manuscript. All authors contributed to data analysis, drafting and revising the paper, and agree to be accountable for all aspects of the work.

\section{Ethics approval and consent to participate}

The protocol was approved by the Scientific and Bioethical committees of the Instituto Nacional de Cancerología (013/014/ICl; CEI/799) and the Instituto Nacional de Enfermedades Respiratorias in Mexico (C12-12). The protocol is registered in www.clinicaltrials.gov (NCT01580579). All patients signed informed consent.

\section{Competing interests}

The authors declare that they have no competing interests.

\section{Publisher's Note}

Springer Nature remains neutral with regard to jurisdictional claims in published maps and institutional affiliations.

\section{Author details}

${ }^{1}$ Subdirección de Investigación Clínica, INER, Calz. de Tlalpan 4502, Tlalpan, Sección XVI, C.P. 14080, Ciudad de México, México. ${ }^{2}$ Departamento de Fisiología Respiratoria INER, México city, México. ${ }^{3}$ Unidad Funcional de Oncología Torácica, Instituto Nacional de Cancerología (INCAN), Av. San Fernando No. 22, Col. Sección XVI, Tlalpan, 14080 Ciudad de México, CP, Mexico. ${ }^{4}$ Departamento de Investigación en Epidemiología y Ciencias Sociales en Salud, Instituto Nacional de Enfermedades Respiratorias (INER), México city, Mexico. ${ }^{5}$ Departamento de Radio-Oncología, INCAN, México city, Mexico. ${ }^{6}$ Thoracic Oncology Unit, Instituto Nacional de Cancerología, Ciudad de México, México.

Received: 21 December 2017 Accepted: 10 April 2018

Published online: 24 April 2018

\section{References}

1. Bray F, Ren JS, Masuyer E, Ferlay J. Global estimates of cancer prevalence for 27 sites in the adult population in 2008. Int J Cancer [Internet]. 2013;132: 1133-45. Available from: http://globocan.iarc.fr/Pages/burden_sel.aspx 
2. Arrieta O, Guzman E, Bouscout LT, Garza JD La, Sancho CG, Lever AP, et al. Cancer de Pulmón de Células No Pequeñas, Clinicas Oncológicas de Iberoamerica, Consenso Nacional de Cancer de Pulmón de México. 2016;

3. Sause W, Kolesar P, Taylor S, Johnson D, Livingston R, Komaki R, et al. Final results of phase III trial in regionally advanced Unresectable non-small cell lung Cancer: radiation therapy oncology group, eastern cooperative oncology group, and southwest oncology group. Chest. 2000;117:358-64.

4. Aupérin A, Le Péchoux C, Rolland E, Curran WJ, Furuse K, Fournel P, et al. Meta-analysis of concomitant versus sequential radiochemotherapy in locally advanced non-small-cell lung cancer. J Clin Oncol [Internet]. Centre for Reviews and Dissemination (UK). 2010 [cited 2016 Nov 15];28:2181-2190. Available from: http://www.ncbi.nlm.nih.gov/pubmed/20351327.

5. Vokes EE, Herndon JE, Kelley MJ, Cicchetti MG, Ramnath N, Neill H, et al. Induction Chemotherapy Followed by Chemoradiotherapy Compared With Chemoradiotherapy Alone for Regionally Advanced Unresectable Stage III Non-Small-Cell Lung Cancer: Cancer and Leukemia Group B. Clin Oncol [Internet]; 2007 [cited 2016 Sep 19];25:1698-1704. Available from: http://www.ncbi.nlm.nih.gov/pubmed/17404369.

6. Steuer CE, Behera M, Ernani V, Higgins KA, Saba NF, Shin DM, et al. Comparison of Concurrent Use of Thoracic Radiation With Either Carboplatin-Paclitaxel or Cisplatin-Etoposide for Patients With Stage III Non-Small-Cell Lung Cancer. JAMA Oncol [Internet]. 2016 [cited 2016 Dec 30]; Available from: http:// oncology.jamanetwork.com/article.aspx?doi=10.1001/jamaoncol.2016.4280

7. Villarreal-Garza C, de la Mata D, Zavala DG, Macedo-Perez EO, Arrieta O. Aggressive treatment of primary tumor in patients with non-small-cell lung Cancer and exclusively brain metastases. Clin Lung Cancer. 2013;14:6-13.

8. Arrieta O, Villarreal-Garza C, Zamora J, Blake-Cerda M, de la Mata MD, Zavala DG, et al. Long-term survival in patients with non-small cell lung cancer and synchronous brain metastasis treated with whole-brain radiotherapy and thoracic chemoradiation. Radiat Oncol [Internet]. BioMed Central; 2011 [cited 2016 Nov 15];6:166. Available from: http://ro-journal.biomedcentral. com/articles/10.1186/1748-717X-6-166

9. Gomez DR, Blumenschein GR, Lee JJ, Hernandez M, Ye R, Camidge DR, et al. Local consolidative therapy versus maintenance therapy or observation for patients with oligometastatic non-small-cell lung cancer without progression after first-line systemic therapy: a multicentre, randomised, controlled, phase 2 study. Lancet Oncol [lnternet]. 2016 [cited 2016 Dec 30]; 17:1672-1682. Available from: http://linkinghub.elsevier.com/retrieve/pii/ S1470204516305320

10. Villarreal-Garza C, de la Mata D, Zavala DG, Macedo-Perez EO, Arrieta O. Aggressive Treatment of Primary Tumor in Patients With Non-Small-Cell Lung Cancer and Exclusively Brain Metastases. Clin Lung Cancer [Internet]. 2013 [cited 2016 Dec 30];14:6-13. Available from: http://linkinghub.elsevier. com/retrieve/pii/S1525730412000848

11. Arrieta O, Luna Palencia RL, Macedo-Pérez O, Barron F, Corona Cruz JF, Chinchilla Trigos LA, et al. P1.06-007 Radical Treatment of Synchronous Oligometastatic Non-Small Cell Lung Cancer (NSCLC). J Thorac Oncol [Internet]. 2017 [cited 2017 Mar 29];12:S668-S669. Available from: http://linkinghub.elsevier.com/retrieve/pii/S1556086416321128

12. Rodrigues G, Lock M, D'Souza D, Yu E, Van Dyk J, Armstrong J, et al. Prediction of radiation pneumonitis by dose - volume histogram parameters in lung cancer-a systematic review. Radiother Oncol [Internet]. Elsevier; 2004 [cited 2016 Dec 22];71:127-138. Available from: http://www. ncbi.nlm.nih.gov/pubmed/15110445.

13. Kim M, Lee J, Ha B, Lee R, Lee K-J, Suh HS. Factors predicting radiation pneumonitis in locally advanced non-small cell lung cancer. Radiat Oncol J [Internet]. Korean Society for Therapeutic Radiology and Oncology; 2011 [cited 2016 Sep 19];29:181-190. Available from: http://www.ncbi.nlm.nih gov/pubmed/22984669.

14. Rancati T, Ceresoli GL, Gagliardi G, Schipani S, Cattaneo GM. Factors predicting radiation pneumonitis in lung cancer patients: a retrospective study. Radiother Oncol. 2003;67:275-83.

15. Bradley JD, Hope A, El Naqa I, Apte A, Lindsay PE, Bosch W, et al. \{A figure is presented\}A Nomogram to Predict Radiation Pneumonitis, Derived From a Combined Analysis of RTOG 9311 and Institutional Data. Int J Radiat Oncol Biol Phys [Internet]. NIH Public Access; 2007 [cited 2016 Dec 22];69:985-992. Available from: http://www.ncbi.nlm.nih.gov/pubmed/17689035.

16. Palma DA, Senan S, Tsujino K, Barriger RB, Rengan R, Moreno M, et al. Predicting radiation pneumonitis after Chemoradiation therapy for lung Cancer: an international individual patient data meta-analysis. Int J Radiat Oncol. 2013;85:444-50.
17. Wen J, Liu H, Wang Q, Liu Z, Li Y, Xiong H, et al. Genetic variants of the LIN28B gene predict severe radiation pneumonitis in patients with nonsmall cell lung cancer treated with definitive radiation therapy. Eur J Cancer [Internet]. 2014 [cited 2016 Dec 30];50:1706-1716. Available from: http://linkinghub.elsevier.com/retrieve/pii/S0959804914002512

18. Jin H, Tucker SL, Liu HH, Wei X, Yom SS, Wang S, et al. Dose-volume thresholds and smoking status for the risk of treatment-related pneumonitis in inoperable non-small cell lung cancer treated with definitive radiotherapy. Radiother Oncol [Internet]. Elsevier; 2009 [cited 2016 Dec 30];91:427-432. Available from: http://www.ncbi.nlm.nih.gov/pubmed/18937989.

19. Robnett TJ, Machtay M, Vines EF, McKenna MG, Algazy KM, McKenna WG, et al. Factors predicting severe radiation pneumonitis in patients receiving definitive chemoradiation for lung cancer. Int J Radiat Oncol Biol Phys [Internet]. Elsevier; 2000 [cited 2016 Dec 30];48:89-94. Available from: http://www.ncbi.n/m.nih.gov/pubmed/10924976.

20. Kong FM (Spring), Wang S. Nondosimetric Risk Factors for RadiationInduced Lung Toxicity. Semin Radiat Oncol [Internet]. Elsevier; 2015;25:100109. Available from: https://doi.org/10.1016/j.semradonc.2014.12.003

21. Arrieta O, Gallardo-Rincón D, Villarreal-Garza C, Michel RM, Astorga-Ramos AM, Martínez-Barrera L, et al. High Frequency of Radiation Pneumonitis in Patients with Locally Advanced Non-small Cell Lung Cancer Treated with Concurrent Radiotherapy and Gemcitabine after Induction with Gemcitabine and Carboplatin. J Thorac Oncol [Internet]. 2009 [cited 2016 Dec 30];4:845-852. Available from: http://linkinghub.elsevier.com/retrieve/ pii/S1556086415324242

22. Wang D, Zhu J, Sun J, Li B, Wang Z, Wei L, et al. Functional and biologic metrics for predicting radiation pneumonitis in locally advanced non-small cell lung cancer patients treated with chemoradiotherapy. Clin Transl Oncol [Internet]. 2012 [cited 2016 Dec 30];14:943-952. Available from: http://www. ncbi.nlm.nih.gov/pubmed/22855174

23. Dehing-Oberije C, De Ruysscher D, van Baardwijk A, Yu S, Rao B, Lambin P, et al. The importance of patient characteristics for the prediction of radiation-induced lung toxicity. Radiother Oncol [Internet]. Elsevier; 2009 [cited 2016 Dec 30];91:421-426. Available from: http://www.ncbi.nlm.nih. gov/pubmed/19147245.

24. Chen S, Zhou S, Zhang J, Yin F-F, Marks LB, Das SK. A neural network model to predict lung radiation-induced pneumonitis. Med Phys [Internet]. 2007 [cited 2016 Dec 30];34:3420-3427. Available from: http://www.ncbi.nlm.nih. gov/pubmed/17926943

25. Ferrero C, Badellino S, Filippi AR, Focaraccio L, Levra MG, Levis M, et al. Pulmonary function and quality of life after VMAT-based stereotactic ablative radiotherapy for early stage inoperable NSCLC: a prospective study. Lung Cancer [Internet]. 2015 [cited 2018 Feb 22]:89:350-356. Available from: https://www.sciencedirect.com/science/article/pii/S0169500215300039.

26. Wang J, Cao J, Yuan S, Ji W, Arenberg D, Dai J, et al. Poor baseline pulmonary function may not increase the risk of radiation-induced lung toxicity. Int J Radiat Oncol Biol Phys [Internet]. Elsevier; 2013 [cited 2016 Dec 30];85:798-804. Available from: http://www.ncbi.nlm.nih.gov/pubmed/ 22836048.

27. Kong F-M, Hayman JA, Griffith KA, Kalemkerian GP, Arenberg D, Lyons S, et al. Final toxicity results of a radiation-dose escalation study in patients with non-small-cell lung cancer (NSCLC): predictors for radiation pneumonitis and fibrosis. Int J Radiat Oncol Biol Phys [Internet]. Elsevier; 2006 [cited 2016 Dec 30];65:1075-1086. Available from: http://www.ncbi. nlm.nih.gov/pubmed/16647222.

28. Tsujino K, Hirota S, Endo M, Obayashi K, Kotani Y, Satouchi M, et al. Predictive value of dose-volume histogram parameters for predicting radiation pneumonitis after concurrent chemoradiation for lung cancer. Int J Radiat Oncol [Internet]. Elsevier; 2003 [cited 2016 Dec 30];55:110-115. Available from: http://linkinghub.elsevier.com/retrieve/pii/ S0360301602038075

29. Yamashita H, Kobayashi-Shibata S, Terahara A, Okuma K, Haga A, Wakui R, et al. Prescreening based on the presence of $\mathrm{CT}$-scan abnormalities and biomarkers (KL-6 and SP-D) may reduce severe radiation pneumonitis after stereotactic radiotherapy. Radiat Oncol [Internet]. BioMed Central; 2010 [cited 2016 Sep 19]:5:32. Available from: http://www.ncbi.nlm.nih.gov/ pubmed/20459699.

30. Budczies J, Klauschen F, Sinn B V, Zs B, Rffy G", Schmitt WD, et al. Cutoff Finder: A Comprehensive and Straightforward Web Application Enabling Rapid Biomarker Cutoff Optimization. PLoS One [Internet]. 2012 [cited 2017 Mar 6];7. Available from: http://molpath.charite.de/cutoff. 
31. Abratt RP, Morgan GW, Silvestri G, Willcox P. Pulmonary complications of radiation therapy. Clin Chest Med. 2004;25:167-77.

32. Parashar B, Edwards A, Mehta R, Pasmantier M, Wernicke AG, Sabbas A, et al. Chemotherapy Significantly Increases the Risk of Radiation Pneumonitis in Radiation Therapy of Advanced Lung Cancer. Am J Clin Oncol [Internet]. 2010 [cited 2016 Nov 15];1. Available from: https://www.ncbi.nlm.nih.gov/ pubmed/20498591.

33. Salinas F V, Winterbauer RH. Radiation pneumonitis: a mimic of infectious pneumonitis. Semin Respir Infect [Internet]. 1995 [cited 2016 Sep 19];10: 143-153. Available from: http://www.ncbi.nlm.nih.gov/pubmed/7481128.

34. Johansson S, Bjermer L, Franzen L, Henriksson R. Effects of ongoing smoking on the development of radiation-induced pneumonitis in breast cancer and oesophagus cancer patients. Radiother Oncol. 1998:49:41-7.

35. Hildebrandt MAT, Komaki R, Liao Z, Gu J, Chang JY, Ye Y, et al. Genetic Variants in Inflammation-Related Genes Are Associated with Radiation-Induced Toxicity Following Treatment for Non-Small Cell Lung Cancer. Cordes N, editor. PLoS One [lnternet]. Public Library of Science; 2010 [cited 2016 Dec 2];:e12402. Available from: http://dx.plos.org/10.1371/journal.pone.0012402

36. Janjigian YY, McDonnell K, Kris MG, Shen R, Sima CS, Bach PB, et al. Packyears of cigarette smoking as a prognostic factor in patients with stage IIIB/ IV nonsmall cell lung cancer. Cancer [Internet]. Wiley Subscription Services, Inc., A Wiley Company; 2010 [cited 2016 Dec 2];116:670-675. Available from: http://doi.wiley.com/10.1002/cncr.24813

37. Arrieta O, Cardona AF, Martín C, Más-López L, Corrales-Rodríguez L, Bramuglia $G$, et al. Updated Frequency of EGFR and KRAS Mutations in NonSmall-Cell Lung Cancer in Latin America: The Latin-American Consortium for the Investigation of Lung Cancer (CLICaP). J Thorac Oncol [Internet]. 2015 [cited 2016 Dec 30];10:838-843. Available from: http:// linkinghub.elsevier.com/retrieve/pii/S1556086415323984

38. Arrieta O, Ramírez-Tirado L-A, Báez-Saldaña R, Peña-Curiel O, Soca-Chafre G, Macedo-Perez E-O. Different mutation profiles and clinical characteristics among Hispanic patients with non-small cell lung cancer could explain the "Hispanic paradox". Lung Cancer [Internet]. 2015 [cited 2016 Dec 30];90:161-166. Available from: http://inkinghub.elsevier.com/retrieve/pii/S0169500215300349

39. Kong F-M (spring), Ritter T, Quint DJ, Senan S, Gaspar LE, Komaki RU, et al. Consideration of dose limits for organs at risk of thoracic radiotherapy: atlas for lung, proximal bronchial tree, esophagus, spinal cord, ribs, and brachial plexus. Int J Radiat Oncol 2011;81:1442-1457.

40. Borst GR, Ishikawa M, Nijkamp J, Hauptmann M, Shirato H, Onimaru R, et al. Radiation pneumonitis in patients treated for malignant pulmonary lesions with hypofractionated radiation therapy. Radiother Oncol [Internet]. Elsevier; 2009 [cited 2016 Dec 28];91:307-313. Available from: http://www.ncbi.nlm. nih.gov/pubmed/19321217.

41. Larici AR, del Ciello A, Maggi F, Santoro SI, Meduri B, Valentini V, et al. Lung abnormalities at multimodality imaging after radiation therapy for non-small cell lung cancer. Radiographics [Internet]. Radiological Society of North America; 2011 [cited 2016 Sep 19];31:771-789. Available from: http://pubs. rsna.org/doi/10.1148/rg.313105096

42. Giridhar P, Mallick S, Rath GK, Julka PK. Radiation Induced Lung Injury: Prediction, Assessment and Management. Asian Pacific J Cancer Prev [lnternet] 2015 [cited 2016 Dec 22];16:2613-2617. Available from: http://koreascience.or. $\mathrm{kr} /$ journal/view.jsp?kj=POCPA9\&py $=2015 \& \mathrm{vnc}=\mathrm{v} 16 \mathrm{n} 7 \& \mathrm{sp}=2613$

43. Ojanguren I, Cruz MJ, Villar A, Barrecheguren M, Morell F, Muñoz X. Utility of Exhaled Nitric Oxide Fraction for the Diagnosis of Hypersensitivity Pneumonitis. Lung [Internet]. 2016 [cited 2016 Dec 22];194:75-80. Available from: http://www.ncbi.nlm.nih.gov/pubmed/26566790.

44. Haccuria A, Michils A, Ebastien Michiels S, Van Muylem A. Exhaled nitric oxide: A biomarker integrating both lung function and airway inflammation changes. J Allergy Clin Immunol. 2014:134:554-9.

45. Sabatelli L, Seppälä U, Sastre J, Crater G. Cost-effectiveness and budget impact of routine use of fractional exhaled nitric oxide monitoring for the Management of Adult Asthma Patients in Spain running title: cost-effectiveness of routine use of FeNO. J Investig Allergol Clin Immunol. 2017;27(2):89-97.

46. Beerthuizen T, Voorend-van Bergen S, van den Hout WB, Vaessen-Verberne AA, Brackel HJ, Landstra AM, et al. Cost-effectiveness of FE NO -based and web-based monitoring in paediatric asthma management: a randomised controlled trial. Thorax [Internet]. 2016 [cited 2016 Dec 22];71:607-613. Available from: http://www.ncbi.nlm.nih.gov/pubmed/27048197.

\section{Ready to submit your research? Choose BMC and benefit from:}

- fast, convenient online submission

- thorough peer review by experienced researchers in your field

- rapid publication on acceptance

- support for research data, including large and complex data types

- gold Open Access which fosters wider collaboration and increased citations

- maximum visibility for your research: over $100 \mathrm{M}$ website views per year

At BMC, research is always in progress.

Learn more biomedcentral.com/submissions 